2021 • Fall - Güz • Volume - Cilt: 12 • Issue - Sayı: 47

\title{
Fear of Missing Out and Problematic Social Media Use: A Research Among University Students in Turkey
}

\begin{abstract}
Ahmet ÇETINKAYA, Marmara University, Faculty of Communication, Associate Professor, ahmet@marmara.edu.tr, (DD 0000-0001-6272-5566
\end{abstract}

Ali Murat KIRIK, Marmara University, Faculty of Communication, Associate Professor, murat.kirik@marmara.edu.tr, (D) 0000-0002-5771-4843

Uğur GÜNDÜZ, İstanbul University, Faculty of Communication, Professor, ugunduz@gmail.com, (iD) 0000-0002-6138-6758

ABSTRACT

This study examines the relationship of fear of missing out (FOMO) with heavy social networking among Turkish university students (aged 17 - 55). Factor analysis of FOMO scale led us to evaluate the construct under two dimensions as (1) fear of missing experience and (2) fear of missing activity. The results revealed that fear of missing activity increases social media intrusion while fear of missing experience is found to have no significant effect. The reverse relationship is also valid: an urge to use social media predicts fear of missing out (activity and experience). Fear of missing experience is associated with problematic social media use (PSMU) and a high desire to use social media.

Keywords : $\quad$ Fear of missing out (FOMO), Problematic Social Media Use (PSMU), Social Media Addiction, Social Media Intrusion

\section{FOMO ve Problemli Sosyal Medya Kullanımı: Türkiye'deki Üniversite Öğrencileri Üzerinde Bir Araştırma}

$\ddot{O Z Z}$

\begin{abstract}
Bu çalışma gelişmeleri kaçırma korkusu (FOMO) ve aşırı sosyal medya kullanımı arasındaki ilişkiyi Türkiye'deki üniversite öğrencileri (17-55 yaş aralı̆̆ı) üzerinde incelemektedir. FOMO ölçeğine ait faktör analizi söz konusu kavramın iki boyut olarak değerlendirilebileceğini göstermiştir: (1) Deneyim kaçırma korkusu ve (2) Aktivite kaçırma korkusu. Sonuçlar aktivite kaçırma korkusunun problemli sosyal medya kullanımın arttırdığın ancak deneyim kaçırma korkusunun önemli bir etkisinin olmadığın göstermiş̧ir. Bu ilişkinin ters yönde de geçerli olduğu görülmüştür: Sosyal medya kullanımı tutkusu gelişmeleri kaçırma korkusunda (aktivite ve deneyim) artışa yol açmıştır. Deneyim kaçırma korkusu problemli sosyal medya kullanımı (PSMU) ve sosyal medya kullanma arzusu ile ilişkilidir.
\end{abstract}




\begin{abstract}
Anahtar : $\quad$ Gelişmeleri Kaçırma Korkusu (FOMO), Problemli Sosyal Medya Kullanımı (PSMU), Kelimeler Sosyal Medya Bağımlılığı, Sosyal Medya Kullanımı Tutkusu
\end{abstract}

\title{
1. INTRODUCTION
}

The communication technologies developed in recent years have gradually increased individualization, and user-centered technologies such as websites, blogs, social networks and video sharing platforms have become prominent. Increased individualization has reshaped communication flows.

With the development of technology, the media have come a long way, and the introduction of computers and mobile phones into all aspects of life-style has increased the usage of media considerably. Capable of making instant communication possible over thousands of kilometers, technical media has gained influence over various aspects of people's lives, reducing the importance of political borders and making globalization possible. Initially used only by military and administrative authorities, the internet has rapidly come to be used in all areas of life, including corporate networks, commercial institutions, scientific, social and personal research and artistic activities (Crowley and Heyer, 2011, p. 47).

In 1979, Truscott \& Ellis created a virtual network through which internet users could share public messages and laid the foundation of social media (cited in Kaplan and Haenlein, 2010:60). Gündüz (2013, s. 135) makes clear the term, social media, describes a recent trend that is spreading rapidly, and it means essentially the individual using the internet mainly for communication and conversation. Today, social media has emerged as a place where people who oppose mainstream media, monopolization and globalization write and produce their own news. Social media platforms have become the most frequently used means of communication due to the aspects that distinguish them from traditional media. The main aspects of social media are connectivity, conversation, content creation and collaboration. They are important reasons for the increasing popularity of social media (Ang, 2011, p. 34). On social media, people can quickly and easily share content they prepare, regardless of time and place. On social network, users can both follow and be followers. Thus, users can share the content they produce, comment on the content of others and participate in interactions by liking content. Social networks are defined as social media not simply because they influence only information platforms, but because they affect our past and our daily lives (Y1ld1z, 2017, p. 72). Taking the stage as interactive, new media in the 2000s, the internet laid the foundations of an unknown realm with digital publishing, blogs and social networks.

The use of social media is common in Turkey. Turkey Statistical Institute Household Internet usage rate of information and communication technology use was $93.0 \%$ in 2018 , while the young people in the 16-24 age group was $92.4 \%$ in 2019 (TUIK, 2020). According to We Are Social Digital Report 2020, young people in Turkey are active on social media. They use social media most for: entertainment $(60 \%)$, obtaining information $(59 \%)$, spending leisure 


\section{AJIT-e Bilişim Teknolojileri Online Dergisi \\ Academic Journal of Information Tecnology \\ 2021 Fall/Güz - Cilt/Vol: 12 - Sayı/Issue: 47 \\ doi) 10.5824/ajite.2021.04.001.x}

time $(54 \%)$, communicating (53\%), following, and creating trends $(51 \%)$, and education and research (47\%). In addition, $86 \%$ of young people connect to social media at least once a day, $72 \%$ connect a couple of times a day, and a third of young people spend 2.51 hours a day on social media (We Are Social Digital Report, 2020).

The world has become more technologically developed over the past few decades. As well as many increased benefits, several health-related consequences related to excessive internet use have come to the attention of researchers, parents, teachers, and treatment providers (Chandrima et. al., 2020). The need to be on social media and user practices have recently emerged as a subject of interest in communication sciences. Technology becoming widespread, the mobile technologies emerging as a result of modernization and ease of access to social media increase access to information and news considerably. With the innovations they offer, technology and the modern world instill the masses with different types of addiction.

After garnering great interest in the media, the FOMO has recently become a research topic for academic researchers. More specifically, studies have found that people who suffer from the FOMO tend to be in unhealthy relationships with social networking sites. For example, these people are more likely to check their messages while driving and use Facebook immediately after waking up, right before going to sleep and during university courses (Riordan et al., 2018). However, the FOMO may have effects other than those related to social network and social media use and academic motivation.

Excessive Internet use, which is also called uncontrolled use of the Internet, problematic Internet use, net addiction or Internet addiction, causes problems at work/school and in social life (Whang, Lee, \& Chang, 2003; Widyanto, 2007; Mathew \& Raman, 2020). With the increased use of the internet, problematic internet use (PIU) has become a public health concern, and has been associated with symptoms of addiction (Chang et al., 2015; Simcharoen et al., 2018; Spada, 2014) which include excessive or poorly controlled preoccupations, urges, and/or behaviors regarding internet access that lead to physical as well as mental impairment or distress (Mamun \& Griffiths, 2019). PIU can be defined as 'Internet use that is risky, excessive or impulsive in nature leading to adverse life consequences, specifically physical, emotional, social or functional impairment (Moreno, Jelenchick, \& Christakis, 2013, p. 1885).

At this point, we deemed it appropriate to collect all these concepts used by the researchers in connection with the concept of PIU and addiction under a general title as PSMU. PSMU, is defined as an unhealthy excessive form of social media use, which is characterized by a lack of control over the behavior and continued behavior despite adverse life consequences (Franchina et al., 2018; Fang et al., 2020). 
In fact, with the wider diffusion of PSMU, researchers began studying individuals who reported feeling addicted to social media use (Rozgonjuk et. al., 2020). While researchers have moved away from addiction terminology regarding digital technology use (see Panova \& Carbonell, 2018) the potentially negative effects of social media overuse have nonetheless received substantial attention over the past years (Montag et al., 2019).

There is broad consensus in the literature on the positive relationship between PSMU and FOMO, but little is known on the direction of such association. In fact, some literature suggests that FOMO constitutes an important risk factor for the development of PSMU (Bodroža \& Jovanović, 2016; Casale \& Fioravanti, 2015; Ruggieri et al., 2020). A major limitation of that study was that the databases used suffered from restricted range in social media use, with the highest category (almost every day) being endorsed by more than $85 \%$ of females in the samples. This simply cannot capture differences in use as they occur naturalistically. Checking Facebook for 5 minutes almost every day is surely different that spending hours a day on social media sites (Daly, 2018).

Social networks' wide popularity led young people to direct their attention to them. Children and young people who use social media intensively may encounter violent and sexually explicit content or harassment. The unrestricted use of social media causes disorders such as PSMU and may have psychologically harmful effects. Internet was originally designed to facilitate communication and research activities, but the dramatic increase in its use in recent years has led to pathological use (Sato, 2006; Odacı \& Çelik, 2013; Mathew \& Raman, 2020).

PSMU is associated with mental health symptoms, such as anxiety and depression in children and young people (Hoge, Bickham, \& Cantor, 2017). People of all ages and from all strata are at risk of PSMU. PSMU can be found at any age and in any social condition, but most of the research major attention has been currently focused on adolescent because adolescent seem to be a critical period of addiction vulnerability (Pallanti, Bernardi, \& Quercioli, 2006; Mathew \& Raman, 2020). However, research also show significant associations exist between adolescents' social media use and FOMO, a construct which can be defined as a pervasive apprehension that others might be having rewarding experiences from which one is absent, and it is characterized by the desire to stay continually connected with what others are doing (Przybylski, Murayama, DeHaan, \& Gladwell, 2013; Fabris et al., 2020). The danger is especially great for Generation Z. Generation Z spends a lot of time in the digital world and risks addiction because they are active on social media unconsciously and unrestrictedly.

User social media practices appear at the intersection of real-life and virtual life. They provide psychological and emotional satisfaction to users. Accordingly, it is reasonable to expect that emotional support from social media would significantly predict problematic social media use (Fang et al., 2020). The relation between social media and its users' practices and PSMU has not received the attention it should. In its most extreme form, PSMU has been 


\section{AJIT-e Bilişim Teknolojileri Online Dergisi \\ Academic Journal of Information Tecnology \\ 2021 Fall/Güz -Cilt/Vol: 12 - Sayı/Issue: 47 \\ doi) 10.5824/ajite.2021.04.001.x}

considered a behavioural addiction by some researchers (Andreassen et al., 2012; Griffiths et al.,2014; Hussain and Starcevic, 2020).

Furthermore PSMU has been linked to aggression, expression of anger, attention deficit hyperactivity disorder (ADHD) and conduct disorder (Ko et al., 2009; Ko et al., 2012; Ho et al., 2014; Okwaraji et al., 2015; Lee et al., 2018; Hartmann \& Blaszczynski, 2018; Jeong et al., 2019), substance misuse across different youth populations (Liu et al., 2011; Anderson et al., 2017) as well as to FOMO and the need for touch (Elhai, Levine, Dvorak, \& Hall, 2016; Li et al., 2019; Arrivillaga et al., 2020).

Therefore, it is important to examine how research has contributed to our understanding of problematic social networking behavior. PSMU is a relatively recent phenomenon and there are controversies as to how best to conceptualise it (Hussain and Starcevic, 2020). Many studies of PSMU have been conducted. A Facebook survey carried out with 1,000 students by Swedish scientists at Gothenburg University revealed that $85 \%$ of the participants logged on to Facebook once every day, and found that half of them felt they were falling behind socially when they did not do so. A study carried out with 18-34 year-old women found that $34 \%$ connected to Facebook even before going to the bathroom and that $39 \%$ defined themselves as Facebook addicts. It also found that the boyfriends of $49 \%$ broke into or checked on their accounts and that these women thought of this as normal behavior (Abhijit, 2011).

As Drouinet and colleagues (Drouinet al.,2015) stated that "with new, game-changing technologies on the horizon (e.g., Google Glass), it is likely that the problems associated with mobile phones (e.g., phantom vibrations and nomophobia) will be ephemeral anomalies for everyone - until the next set of addictive behaviors and symptoms emerges" (p. 203). The effects of PSMU and problematic smart phone use have made the FOMO the new disorder of today's digital world.

Researchers refer to FOMO as a psychological disorder that manifests itself as PSMU. An experiment with a group in England found that, of 1,000 mobile phone users, $66 \%$ said that they could not live without being called and without using social media (Betoncu and Ozdamli 2019, p. 599).

One of the most widely accepted outcomes of PSMU is that people, especially young people, who are not addicted to anything, have a tendency to FOMO. They do not want to engage in social activities. Even if they want to and agree to join, they may change their mind at the last minute. This is the case especially for big decisions such as which school to attend, who to marry, how to find a job and so on. Most young people think they would make the 
wrong decision if they were to make a decision in any of these areas, or that they have a better option and are missing it (Axis, 2018, p. 8).

PSMU also triggers the FOMO or missing developments. This disease shows itself also in the comments of Van Dijk on losing connection. In fact, according to him, some users think that the loss of connection should be prevented at any cost, and they hope that they will create new and constantly more rewarding connections by making sure their connections are okay (Van Dijk, 2016:367). The FOMO has been conceptualized in many ways as fear of missing opportunities, falling behind, missing trends, not being informed about social interactions, falling short, not being connected, missing experiences and being deprived. The FOMO can thus be described as a state of worry or obsession due to social media fears (Dossey, 2014).

As Maclean (2017) has written, evidence shows that the increasing effect of social media on society increases feelings of loneliness and leads people to think there is a better life than the one they are living now, in other words, to feel the FOMO (p.1). The FOMO is also defined as restlessness and burnout causing mainly children and young people to think their peers have things that are better than what they know or have (Abel et al., 2016, p. 33).

Previous studies have found that when people use or become engrossed in social media, they develop feelings of inadequacy, restlessness, anxiety or worry (Wortham, 2011). It has been reported that the FOMO increases participation on social media platforms and motivates users to use them more. A 2012 study by JWT Intelligence found that $40 \%$ of 12-67 year-old people say that social media increases the FOMO. Only $8 \%$ of the participants said that they feel the FOMO (Abel et al., 2016, pp. 35-36).

There is a strong correlation between the FOMO and social needs. This becomes even more concrete with the findings of a study carried out by Przybylski et al. (2013). Here are their findings:

- $\quad$ The FOMO is the driving force behind the use of social media.

- $\quad$ The FOMO is more prevalent among young people and young men.

- $\quad$ There is a strong correlation between unsatisfied social needs and the FOMO.

- $\quad$ The FOMO is a dangerous distraction for automobile drivers.

- $\quad$ The FOMO is prevalent among students who use social media during classes.

FOMO has been revealed out to emerge as an outcome of various factors including negative social and emotional states (Przybylski et al., 2013), decreased levels of self-regulation (Alt \& Nissim, 2018a; 2018b), need for popularity and need to belong (Beyens et al., 2016) and negative affectivity (Elhai et al., 2018). Its role as a driving factor in social media intensity is of particular interest in the current study. Prior research suggested significant links between FOMO and PSMU. A higher level of FOMO has been found to be a positive predictor of 


\section{AJIT-e Bilişim Teknolojileri Online Dergisi \\ Academic Journal of Information Tecnology \\ 2021 Fall/Güz - Cilt/Vol: 12 - Sayı/Issue: 47 \\ doi) 10.5824/ajite.2021.04.001.x}

increased Facebook use (Blachnio and Przepiorka, 2018; Dempsey et al., 2019; Beyens et al., 2016) and other social media in general (Dhir et al., 2018; Oberst et al., 2017; Przybylski et al., 2013; Wolniewicz et al., 2018; Alt, 2015). Social media addiction, also, has been found to be positively related with FOMO (Blackwell, Leaman, Tramposch, Osborne, \& Liss, 2017).

In general, PSMU and problematic smartphone use seem to be widespread and related with a variety of negative psychological disorders, such as anxiety, depression, neuroticism, poor sleep, and stress. Social media allows people high on FOMO to not only monitor the activities of others, but also share their own experiences online (Rogers et. al., 2019). Additionally, use of social media may allow those high on FOMO to fulfill basic needs for relatedness, autonomy and competence (Przybylski et al., 2013). Several recent studies have demonstrated a relatively strong link between FOMO and problematic smartphone and Internet use (Alt\&Nissim, 2018a; 2018b; Elhai, Levine, Dvorak, \& Hall, 2016; Gezgin, 2018; Wolniewicz, Tiamiyu, Weeks, \& Elhai, 2018; Rozgonjuk et al., 2019) Also PSMU is an antecedent of emotion dysregulation as previous studies indicated that problematic uses of technology are likely to co-occur with emotional distress (Marino et al., 2020).

Social networking sites often exacerbate FOMO due to the ability of users to manage the way that others view them by presenting a perfect image of who they are, that is, selfpresentation and impression management (Crabtree \& Pillow, 2018). Activities such as censoring, exaggerating, and even lying about ones' life when creating online content can achieve FoMO that results in others feeling envy, and overall, less worthy, less happy, and even unsuccessful by comparison (Chou \& Edge, 2012; Jordan et al., 2011).

Therefore, the media furor may not be entirely unfounded FOMO, PSMU and problematic smartphone use, whether they are considered independently or part of the same construct, are real problems within modern society. Moreover, people are becoming aware of their addictions, and in the coming years, it is likely that many people will seek treatment for their addictions. Fortunately for these people, help appears to be abundant: a Google search for FOMO returned more than 9.690 .000 hits.

This study examines the correlations between social media intrusion, PSMU and FOMO. Social media intrusion is characterized by three elements: social media intensity, use of social media in inappropriate situations and the desire to use social media. FOMO construct is analyzed further to understand the contributions of its building factors. The research questions are as follows:

- What are the building blocks of FOMO?

- $\quad$ Is there a relationship between social media intrusion and FOMO? 
- $\quad$ Is there a relationship between PSMU and FOMO?

- $\quad$ Is there a relationship between social media intrusion and PSMU?

- $\quad$ Are there socio-demographic differences in social media intrusion and in scores of FOMO and PSMU?

\section{METHODS}

\subsection{Participants and Procedure}

In order to gather data for constructs, we implemented a questionnaire with measurement items from literature. The study was conducted on private and public university students in Turkey. We created the questionnaire on Google Forms, and the survey's URL was posted in authors' social media accounts and WhatsApp groups of students and made accessible between January and April 2019.

A total of 500 questionnaires were completed. Of this amount, 22 had the same answer on all items, and 5 had missing values, so totally 27 surveys were removed. Overall, there were 473 completed surveys (290 women, 183 men) available for data analysis; none of them containing missing data. Participants ranged in age from 17 to $55(\mathrm{M}=23.32, \mathrm{SD}=5.50)$. Other descriptive statistics of the sample are given in Table 1.

Table 1: Descriptive statistics of the participants

\begin{tabular}{llll}
\hline Statistics & & $\mathrm{N}$ & $\%$ \\
\hline \multirow{3}{*}{ Degree enrolled } & Undergraduate & 396 & 83.5 \\
& Master's & 57 & 12.0 \\
& PhD & 21 & 4.50 \\
\cline { 2 - 4 } Flass enrolled & Sophomore & 70 & 14.8 \\
& Junior & 83 & 17.5 \\
& Senior & 135 & 28.5 \\
& Master's & 113 & 23.9 \\
& PhD & 51 & 10.8 \\
\cline { 2 - 4 } Family well-being & Very poor & 5 & 4.4 \\
& Poor & 50 & 1.1 \\
& Adequate & 277 & 10.6 \\
& Good & 131 & 58.6 \\
& Very good & 10 & 27.7 \\
\cline { 2 - 4 } Mother's educational level & Primary school & 211 & 2.1 \\
\cline { 2 - 3 } & Secondary school & 148 & 44.6 \\
& Associates & 54 & 31.3 \\
& Bachelor's degree & 54 & 11.4 \\
& & & 11.4
\end{tabular}




\begin{tabular}{llll} 
& Master's degree & 5 & 1.1 \\
& PhD & 1 & 0.2 \\
\cline { 2 - 4 } & Primary school & 148 & 31.3 \\
& Secondary school & 174 & 36.8 \\
Father's educational level & Associates & 57 & 12.1 \\
& Bachelor's degree & 79 & 16.7 \\
& Master's degree & 8 & 1.7 \\
& PhD & 7 & 1.5 \\
\hline
\end{tabular}

\subsection{Measures}

We administrated 6 different scales to measure: social media intrusion, FOMO level, and PSMU.

Each scale used in this study has been employed in numerous research and found as reliable measurements. All scales are measured on 5-point Likert scale ranging from 1 (strongly disagree) to 5 (strongly agree). The scales were translated into Turkish. To ensure conceptual consistency, back translations were performed by a group of academicians fluent in English and Turkish.

\subsection{Socio-Demographic Questions}

We queried the following demographic variables of the respondents: age, gender, degree and class enrolled, family well-being and parents' educational level.

\subsection{Social Media Intensity Scale}

Facebook Intensity Scale (Ellison et al., 2007) was often modified to assess more broad social media intensity in the literature (Chu et al., 2016; Roberts \& David, 2020; Thoumrungroje, 2014). It measures any emotional attachment to social media and how much it intrudes into one's life. The 6-item scale adapted by Roberts \& David (2020) is used in this study. The Cronbach's alpha was 0.86 in the present sample.

\subsection{Social Media Use}

We used the scale developed by Hetz et al., (2015) to measure the participants' use of social media in inappropriate times such as during meals, just before sleeping or just after waking up. The tool consists of 5 questions. The Cronbach's alpha was 0.84 in the present sample.

\subsection{Social Media Usage Urges}

To assess the urge to check social media, four situations considered by Abel et al. (2016) are referred. Abel et al. (2016) evaluated the differences in the urge to check social media 
among respondents with high and low levels of FOMO. The four situations question the desire to log into social media when one is alone or together with people or during classes.

\subsection{Fear of Missing Out Scale}

Developed by Przybylski et al., (2013), the scale measures at what level participants experience FOMO on the activities and events their friends have. The tool consists of 10 questions. Two dimensions were found in the scale in factor analysis. These two subdimensions of the FOMO scale are named as: Fear of Missing Experience (FOME) and Fear of Missing Activity (FOMA). The Cronbach's alphas were 0.86 for FOME and 0.72 for FOMA. Table 2 gives the factor loading of each scale item and the variances.

Table 2: FOMO scale factor analysis results

\begin{tabular}{|c|c|c|c|}
\hline $\begin{array}{l}\text { Factor } \\
\text { Name }\end{array}$ & Factor Item & $\begin{array}{l}\text { Factor } \\
\text { Loading }\end{array}$ & $\begin{array}{l}\text { Variance } \\
(\%)\end{array}$ \\
\hline \multirow{4}{*}{$\begin{array}{l}\text { Fear of } \\
\text { Missing } \\
\text { Experience } \\
\text { (FOME) }\end{array}$} & $\begin{array}{l}\text { I fear my friends have more rewarding experiences } \\
\text { than me. }\end{array}$ & 0.892 & \multirow{4}{*}{50.693} \\
\hline & I fear others have more rewarding experiences than & 0.887 & \\
\hline & $\begin{array}{l}\text { I get worried when I find out my friends are having } \\
\text { fun without me. }\end{array}$ & 0.755 & \\
\hline & $\begin{array}{l}\text { I get anxious when I don't know what my friends are } \\
\text { up to. }\end{array}$ & 0.714 & \\
\hline \multirow{3}{*}{$\begin{array}{l}\text { Fear of } \\
\text { Missing } \\
\text { Activity } \\
\text { (FOMA) }\end{array}$} & When I miss out on a planned get-together it bothers & 0.866 & \multirow{3}{*}{18.290} \\
\hline & $\begin{array}{l}\text { It bothers me when I miss an opportunity to meet up } \\
\text { with friends }\end{array}$ & 0.838 & \\
\hline & It is important that I understand my friends in jokes. & 0.584 & \\
\hline
\end{tabular}

\section{Bergen Social Media Addiction Scale}

PSMU is assessed by the Bergen Social Media Addiction Scale (Andreassen et al., 2017). The scale consists of 6 items, and it is an adapted version of the Bergen Facebook Addiction Scale (BFAS) (Andreassen et al., 2012). It rephrases the BFAS. The Cronbach's alpha was 0.81 in the present sample.

\section{ANALYSIS AND RESULTS}

\subsection{Regression Analyses}

Bivariate correlations between all variables can be seen in Table-4. In order to test the relationship between social media intensity and other variables in the model, we carried out 


\section{AJIT-e Bilişim Teknolojileri Online Dergisi \\ Academic Journal of Information Tecnology \\ 2021 Fall/Güz - Cilt/Vol: 12 - Sayı/Issue: 47 \\ 10.5824/ajite.2021.04.001.x}

multiple linear regression analysis with social media intensity being the dependent variable. The significant predictors of social media intensity are given in Table 5. ( $R=0.750, R^{2}=0.562$, $\mathrm{F}=154.594, \mathrm{p}=.000$ ). The contributions of the remaining variables were insignificant and small in magnitude. Thus, FOMA had contribution on social media intensity whereas FOME did not.

Table 3: Intercorrelations among study variables

\begin{tabular}{lllllll}
\hline & 1 & 2 & 3 & 4 & 5 & 6 \\
\hline 1. Social Media Intensity & 1 & & & & & \\
2. Fear of Missing Experience & $0.320^{* *}$ & 1 & & & & \\
3. Fear of Missing Activity & $0.378^{* *}$ & $0.465^{* *}$ & 1 & & & \\
4. Social Media Use & $0.627^{* *}$ & $0.296^{* *}$ & $0.259^{* *}$ & 1 & & \\
5. Social Media Usage Urges & $0.661^{* *}$ & $0.362^{* *}$ & $0.349^{* *}$ & $0.644^{* *}$ & 1 & \\
6. SNS Addiction & $0.598^{* *}$ & $0.398^{* *}$ & $0.370^{* *}$ & $0.537^{* *}$ & $0.616^{* *}$ & 1 \\
Average & 3.31 & 2.53 & 3.44 & 2.88 & 3.04 & 2.63 \\
SD & 0.89 & 0.97 & 0.88 & 0.95 & 0.84 & 0.84 \\
\hline
\end{tabular}

${ }^{*} \mathrm{p}<0.05^{* *} \mathrm{p}<0.01$

To assess the contributions of social media intrusion and PSMU on the two dimensions of FOMO, multiple linear regression analyses were conducted with FOMA and FOME being the dependent variables. The results of the analyses are given in

Table 5 for FOMA $\left(\mathrm{R}=0.408, \mathrm{R}^{2}=0.166, \mathrm{~F}=46.828, \mathrm{p}=.000\right)$ and in

Table 6 for FOME $\left(\mathrm{R}=0.422, \mathrm{R}^{2}=0.178, \mathrm{~F}=51.040\right.$, $\left.\mathrm{p}=.000\right)$. The variables not included in the tables had insignificantly small contributions.

Table 4: Predictors of social media intensity

\begin{tabular}{llll}
\hline Independent Variables & Beta & $\mathrm{t}$-value & p-value \\
\hline Social Media Usage Urges & 0.331 & 7.555 & 0.000 \\
Social Media Use & 0.276 & 6.810 & 0.000 \\
Social Media Addiction & 0.210 & 5.192 & 0.000 \\
Fear of Missing Activity & 0.106 & 3.232 & 0.001 \\
\hline
\end{tabular}

Table 5: Predictors of FOMA

\begin{tabular}{llll}
\hline Independent Variables & Beta & t-value & p-value \\
\hline Social Media Addiction & 0.255 & 4.855 & 0.000 \\
Social Media Intensity & 0.200 & 3.813 & 0.010 \\
\hline
\end{tabular}


Table 6: Predictors of FOME

\begin{tabular}{llll}
\hline Independent Variables & Beta & t-value & p-value \\
\hline Social Media Usage Urges & 0.146 & 2.756 & 0.006 \\
Social Media Addiction & 0.316 & 5.956 & 0.000 \\
& & & \\
\hline
\end{tabular}

\subsection{Demographic Associations}

Independent sample t-test was performed to assess whether there exist statistically significant differences in the study variables due to demographics. According to results of the tests, no significant differences were found between different demographic categories for the scores of social media intrusion, PSMU, and FOME. However, as Table 7 shows, there was a difference between male and female scores of FOMA, with men experiencing mildly higher levels of fear of missing activity.

Table 7: Independent sample for gender

\begin{tabular}{lllllll}
\hline \multirow{2}{*}{ FOMA } & Gender & $\mathrm{N}$ & Mean & $\mathrm{SD}$ & $\mathrm{t}$-value & p-value \\
\cline { 2 - 7 } & Female & 290 & 3.382 & 0.883 & \multirow{2}{*}{-2.036} & \multirow{2}{*}{0.042} \\
& Male & 183 & 3.548 & 0.842 & & \\
\hline
\end{tabular}

\subsection{Age Differences}

One-way ANOVA was conducted to compare the effect of age on each study variable. No differences existed for social media intrusion, PSMU and the two dimensions of FOMO.

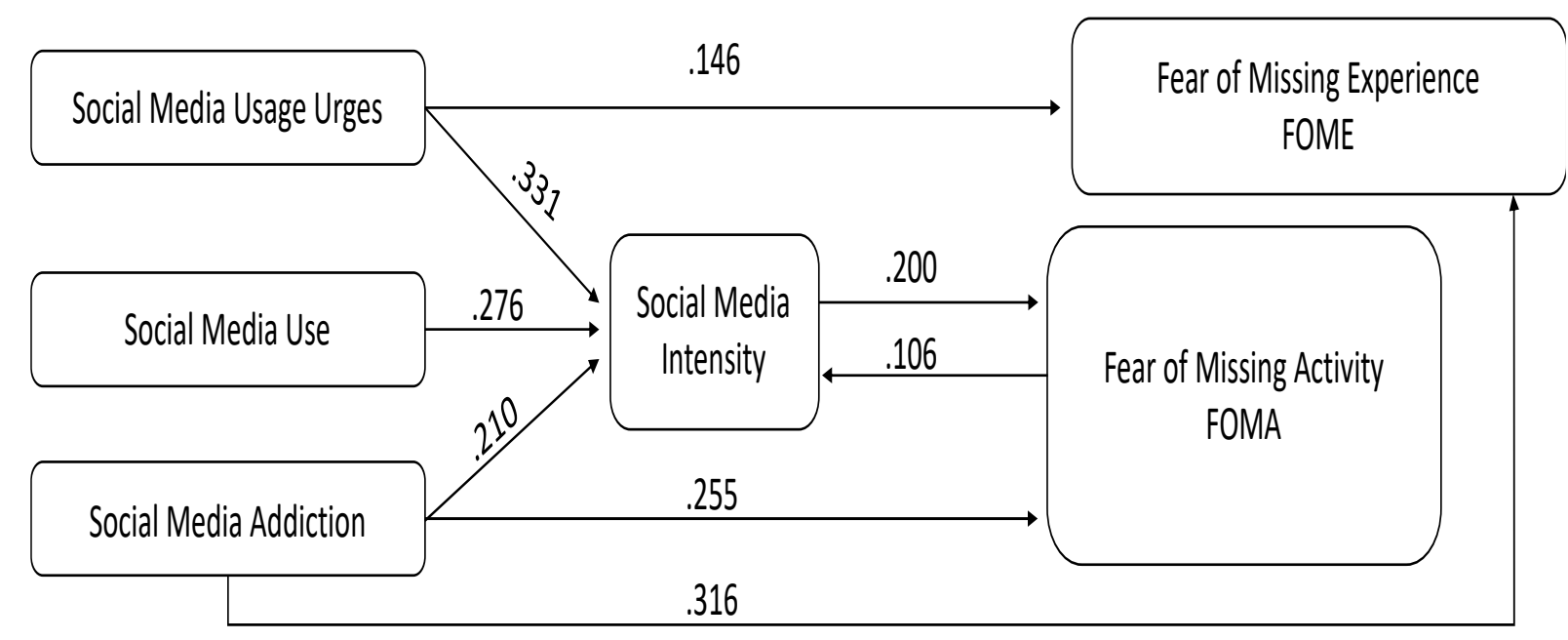


Figure 1: Resulting model

\section{DISCUSSION}

In the present study, we aimed to assess the relationship of FOMO construct with problematic social media use (PSMU) and social media intrusion among university students in Turkey. Desire to check social networking sites at social occasions (social media usage urges), how much one embraces these sites (social media intensity) and logging into them in inappropriate times - such as during meals or just before or after bedtime - (social media use) defined the context of social media intrusion.

Factor analysis of FOMO scale revealed that the contribution of items to latent FOMO factor were different, which enabled us to assess the scale under two dimensions as fear of missing activity -FOMA- and fear of missing experience -FOME-. These sub-factors shed some light on the association of FOMO with social media use habits or PSMU reported both in this study and in previous research (Elhai et al., 2018; Blackwell et al., 2017; Oberst et al., 2017; Beyens et al., 2016; Alt, 2015; Przybylski et al., 2013). FOME came out to be a dimension with more pathological items included. We found that it is the fear of missing activity which leads to elevated social media intensity levels, while the other dimension -fear of missing experience -had no significant effect. The reverse relationship was also found to be true: social media intensity would serve as a predictor of FOMA. We found evidence that FOME was more predicted by social media usage urges. This result is reasonable since we would expect the more pathological fear of missing experience feeling to be experienced more frequently by the ones who have an intense desire to check social media accounts even in social occasions. PSMU, on the other hand, drove both of the FOMO dimensions.

We found evidence of several indirect associations as well. Social media intensity mediated the relations between social media usage urges and FOMA, and between social media use and FOMA. It mediated also the relations between PSMU, also a direct predictor of FOMA as stated earlier, and FOMA.

Figure 1 depicts a summary of the correlations found between social media intrusion, PSMU and the two dimensions of FOMO.

We found no statistically significant effects with demographic variables in neither of social media intrusion, PSMU and FOME. Demographic variables we queried were consisted of age, gender, degree and class enrolled, family well-being and parents' educational level. FOMA, however, was found to be experienced more by men than women. This result supports a prior finding (Przybylski et al, 2013) that reported FOMO to be related to male gender. We contribute on this earlier finding by stating that higher levels of FOMO scores of men are a 
result of FOMA dimension of FOMO. Otherwise, FOME dimension of FOMO exhibited no difference between male and female sex.

Future research could extend the correlation analysis of this study to social groups other than university students. The two dimensions of FOMO suggested in the current study could be taken into consideration to re-evaluate the association of the construct with various factors previously studied in the literature.

\subsection{Limitations}

Our study has limitations to be noted. The results of the study were only due to Turkish university students and cannot be generalized to other cultures. Although the age range of the participants was rather wide, the remaining age groups should also be analyzed. Another limitation was that the majority of the participants were females. This is in part due to women being more willing to participate in questionnaires. Finally, the data was constructed through self-report measures, making the validity of the data depend on the accuracy of the participants' responses.

\section{CONCLUSION}

The main purpose of this study is to find out associations between FOMO and social networking sites use habits among Turkish university students. Our study is the first to reveal two important dimensions of the FOMO construct: fear of missing activity (FOMA) and fear of missing experience (FOME). This is especially important in diagnosing what may be regarded as pathological in fear of missing out feeling. FOME is predicted more with checking social networking sites in social occasions and with PSMU. FOMA, however, is predicted with increased use of social media, even just before sleeping or close after wake up, and thus with increased intrusion of social media in one's life. Different FOMO levels for men and women widely stated in the literature should be further assessed considering the two sub-dimensions of the construct, since the study here revealed it is the fear of missing activity leading to elevated levels of FOMO scores in men. 


\section{AJIT-e Bilişim Teknolojileri Online Dergisi \\ Academic Journal of Information Tecnology \\ 2021 Fall/Güz -Cilt/Vol: 12 - Sayı/Issue: 47 \\ doi) 10.5824/ajite.2021.04.001.x}

\section{REFERENCES}

Abel, J. P., Buff, C. L., \& Burr, S. A. (2016). Social Media and the Fear of Missing Out: Scale Development and Assessment. Journal of Business \& Economics Research (JBER), 14(1), 33-44. https://doi.org/10.19030/jber.v14i1.9554

Abhijit, N. (2011). Facebook Addiction. Available at: http://www.buzzle.com/articles/facebook- addiction.html (accessed 8 October 2018).

Alt, D. (2015). College students' academic motivation, media engagement and fear of missing out. Computers in Human Behavior, 49, 111-119. https://doi.org/10.1016/j.chb.2015.02.057

Anderson, E. L., Steen, E., \& Stavropoulos, V. (2017). Internet use and Problematic Internet Use: A systematic review of longitudinal research trends in adolescence and emergent adulthood. International Journal of Adolescence and Youth, 22(4), 430-454. https://doi.org/10.1080/02673843.2016.1227716

Andreassen, C. S., Torsheim, T., Brunborg, G. S., \& Pallesen, S. (2012). Development of a facebook addiction scale. Psychological Reports, 110(2), 501-517. https://doi.org/10.2466/02.09.18.PR0.110.2.501-517

Andreassen, C. S., Pallesen, S., \& Griffiths, M. D. (2017). The relationship between addictive use of social media, narcissism, and self-esteem: Findings from a large national survey. Addictive Behaviors, 64, 287-293. https://doi.org/10.1016/j.addbeh.2016.03.006

Ang, L. (2011). Community relationship management and social media. Journal of Database Marketing \& Customer Strategy Management, 18(1), 31-38. https://doi.org/10.1057/dbm.2011.3

Arrivillaga, C., Rey, L., \& Extremera, N. (2020). Adolescents' problematic internet and smartphone use is related to suicide ideation: Does emotional intelligence make a difference? Computers in Human Behavior, 110, 106375. https://doi.org/10.1016/j.chb.2020.106375

Axis (2018). A parent's guide to fomo. (2018). David C Cook.

Bányai, F., Zsila, Á., Király, O., Maraz, A., Elekes, Z., Griffiths, M. D., Andreassen, C. S., \& Demetrovics, Z. (2017). Problematic social media use: Results from a large-scale nationally representative adolescent sample. PLOS ONE, 12(1), e0169839. https://doi.org/10.1371/journal.pone.0169839

Betoncu, O. \& Ozdamli, F. (2019). The Disease of 21st Century: Digital Disease.TEM Journal. 8(2). 598-603. https://doi.org/10.18421/TEM82-37

Beyens, I., Frison, E., \& Eggermont, S. (2016). “I don't want to miss a thing”: Adolescents' fear of missing out and its relationship to adolescents' social needs, Facebook use, and Facebook related stress. Computers in Human Behavior, 64, 1-8. https://doi.org/10.1016/j.chb.2016.05.083

Błachnio, A., \& Przepiórka, A. (2018). Facebook intrusion, fear of missing out, narcissism, and life satisfaction: $\begin{array}{llll}\text { A cross-sectional } & \text { 5tudy. Psychiatry }\end{array}$ https://doi.org/10.1016/j.psychres.2017.11.012

Blackwell, D., Leaman, C., Tramposch, R., Osborne, C., \& Liss, M. (2017). Extraversion, neuroticism, attachment style and fear of missing out as predictors of social media use and addiction. Personality and Individual Differences, 116, 69-72. https://doi.org/10.1016/j.paid.2017.04.039 
Bodroža, B., \& Jovanović, T. (2016). Validation of the new scale for measuring behaviors of facebook users: Psycho-social aspects of facebook use(Psafu). Computers in Human Behavior, 54, 425-435. https://doi.org/10.1016/j.chb.2015.07.032

Casale, S., \& Fioravanti, G. (2015). Satisfying needs through Social Networking Sites: A pathway towards problematic Internet use for socially anxious people? Addictive Behaviors Reports, 1, 34-39. https://doi.org/10.1016/j.abrep.2015.03.008

Chandrima, R. M., Kircaburun, K., Kabir, H., Riaz, B. K., Kuss, D. J., Griffiths, M. D., \& Mamun, M. A. (2020). Adolescent problematic internet use and parental mediation: A Bangladeshi structured interview study. Addictive Behaviors Reports, 12, 100288. https://doi.org/10.1016/j.abrep.2020.100288

Chang, F.-C., Chiu, C.-H., Miao, N.-F., Chen, P.-H., Lee, C.-M., Chiang, J.-T., \& Pan, Y.-C. (2015). The relationship between parental mediation and Internet addiction among adolescents, and the association with cyberbullying and depression. Comprehensive Psychiatry, 57, 21-28. https://doi.org/10.1016/j.comppsych.2014.11.013

Chou, H.-T. G., \& Edge, N. (2012). "They are happier and having better lives than i am": The impact of using facebook on perceptions of others' lives. Cyberpsychology, Behavior, and Social Networking, 15(2), 117121. https://doi.org/10.1089/cyber.2011.0324

Chu, S. C., Windels, K., \& Kamal, S. (2016). The influence of self-construal and materialism on social media intensity: A study of China and the United States. International Journal of Advertising, 35(3), 569-588.

Crabtree, M. A., \& Pillow, D. R. (2018). Extending the Dual Factor Model of Facebook Use: Social motives and network density predict Facebook use through impression management and open self$\begin{array}{llll}\text { disclosure. Personality } \quad \text { and } \quad \text { Individual } & \text { Differences, } 133,\end{array}$ https://doi.org/10.1016/j.paid.2017.06.017

Crowley, D. \& Heyer, P. (2011). Illetişim Tarihi: Teknoloji, Kültür, Toplum. (translator: M. Ersöz). Siyasal Kitabevi.

Daly, M. (2018). Social media use may explain little of the recent rise in depressive symptoms among adolescent girls, Clinical Psychological Science, 6: 295.

Dempsey, A. E., O’Brien, K. D., Tiamiyu, M. F., \& Elhai, J. D. (2019). Fear of missing out (Fomo) and rumination mediate relations between social anxiety and problematic Facebook use. Addictive Behaviors Reports, 9, 100150. https://doi.org/10.1016/j.abrep.2018.100150

Dhir, A., Yossatorn, Y., Kaur, P., \& Chen, S. (2018). Online social media fatigue and psychological wellbeingA study of compulsive use, fear of missing out, fatigue, anxiety and depression. International Journal of Information Management, 40, 141-152. https://doi.org/10.1016/j.ijinfomgt.2018.01.012

Dossey, L. (2014). Fomo, digital dementia, and our dangerous experiment. EXPLORE, 10(2), 69-73. https://doi.org/10.1016/j.explore.2013.12.008

Drouinet, M.K., Daren, M. \& Daniel, A. (2015). “Mobile Phone Dependency: What's All the Buzz About?”, in the Wiley Handbook of Psychology, Technology, and Society, eds. Larry D. Rosen, Nancy A. Cheever, and L. Mark Carrier, Wiley Blackwell, 192-206.

Elhai, J. D., Levine, J. C., Dvorak, R. D., \& Hall, B. J. (2016). Fear of missing out, need for touch, anxiety and depression are related to problematic smartphone use. Computers in Human Behavior, 63, 509-516. https://doi.org/10.1016/j.chb.2016.05.079

Elhai, J. D., Levine, J. C., Dvorak, R. D., \& Hall, B. J. (2016). Fear of missing out, need for touch, anxiety and depression are related to problematic smartphone use. Computers in Human Behavior, 63, 509-516. https://doi.org/10.1016/j.chb.2016.05.079 


\section{AJIT-e Bilişim Teknolojileri Online Dergisi \\ Academic Journal of Information Tecnology \\ 2021 Fall/Güz -Cilt/Vol: 12 - Sayı/Issue: 47 \\ doi) 10.5824/ajite.2021.04.001.x}

Ellison, N. B., Steinfield, C., \& Lampe, C. (2007). The benefits of facebook "friends:" social capital and college students' use of online social network sites. Journal of Computer-Mediated Communication, 12(4), 11431168. https://doi.org/10.1111/j.1083-6101.2007.00367.x

Fabris, M. A., Marengo, D., Longobardi, C., \& Settanni, M. (2020). Investigating the links between fear of missing out, social media addiction, and emotional symptoms in adolescence: The role of stress associated with neglect and negative reactions on social media. Addictive Behaviors, 106, 106364. https://doi.org/10.1016/j.addbeh.2020.106364

Fang, J., Wang, X., Wen, Z., \& Zhou, J. (2020). Fear of missing out and problematic social media use as mediators between emotional support from social media and phubbing behavior. Addictive Behaviors, 107, 106430. https://doi.org/10.1016/j.addbeh.2020.106430

Franchina, V., Vanden Abeele, M., van Rooij, A., Lo Coco, G., \& De Marez, L. (2018). Fear of missing out as a predictor of problematic social media use and phubbing behavior among flemish adolescents. International Journal of Environmental Research and Public Health, 15(10), 2319. https://doi.org/10.3390/ijerph15102319

Gezgin, D. M. (2018). Understanding Patterns for Smartphone Addiction: Age, Sleep Duration, Social Network Use and Fear of Missing Out. Cypriot Journal of Educational Sciences, 13(2), 166-177.

Griffiths, M. D., Kuss, D. J., \& Demetrovics, Z. (2014). Social networking addiction. Içinde Behavioral Addictions (ss. 119-141). Elsevier. https://doi.org/10.1016/B978-0-12-407724-9.00006-9

Gündüz, U. (2013). “Toplumsal Hareketler, Sivil İtaatsizlik ve Sosyal Medya Yansımaları”, Sosyalleşen Birey, Sosyal Medya Araştırmaları 1, eds. Ali Büyükarslan, Ali Murat Kırık. Çizgi Kitabevi. 33-154.

Hartmann, M., \& Blaszczynski, A. (2018). The longitudinal relationships between psychiatric disorders and gambling disorders. International Journal of Mental Health and Addiction, 16(1), 16-44. https://doi.org/10.1007/s11469-016-9705-z

Hetz, P. R., Dawson, C. L., \& Cullen, T. A. (2015). Social media use and the fear of missing out (Fomo) while studying abroad. Journal of Research on Technology in Education,47(4), 259-272. https://doi.org/10.1080/15391523.2015.1080585

Ho, R. C., Zhang, M. W., Tsang, T. Y., Toh, A. H., Pan, F., Lu, Y., Cheng, C., Yip, P. S., Lam, L. T., Lai, C.-M., Watanabe, H., \& Mak, K.-K. (2014). The association between internet addiction and psychiatric comorbidity: A meta-analysis. BMC Psychiatry, 14(1), 183. https://doi.org/10.1186/1471-244X-14-183

oge, E., Bickham, D., \& Cantor, J. (2017). Digital media, anxiety, and depression in children. Pediatrics, 140(Supplement 2), S76-S80. https://doi.org/10.1542/peds.2016-1758G

Hussain, Z., \& Starcevic, V. (2020). Problematic social networking site use: A brief review of recent research methods and the way forward. Current Opinion in Psychology, 36, 89-95. https://doi.org/10.1016/j.copsyc.2020.05.007

Jeong, E. J., Ferguson, C. J., \& Lee, S. J. (2019). Pathological gaming in young adolescents: A longitudinal study focused on academic stress and self-control in south korea. Journal of Youth and Adolescence, 48(12), 2333-2342. https://doi.org/10.1007/s10964-019-01065-4

Jordan, A. H., Monin, B., Dweck, C. S., Lovett, B. J., John, O. P., \& Gross, J. J. (2011). Misery has more company than people think: Underestimating the prevalence of others' negative emotions. Personality and Social Psychology Bulletin, 37(1), 120-135. https://doi.org/10.1177/0146167210390822 
Kaplan, A. M., \& Haenlein, M. (2010). Users of the world, unite! The challenges and opportunities of Social Media. Business Horizons, 53(1), 59-68. https://doi.org/10.1016/j.bushor.2009.09.003

Ko, C.-H., Yen, J.-Y., Liu, S.-C., Huang, C.-F., \& Yen, C.-F. (2009). The associations between aggressive behaviors and internet addiction and online activities in adolescents. Journal of Adolescent Health, 44(6), 598-605. https://doi.org/10.1016/j.jadohealth.2008.11.011

Ko, C.-H., Yen, J.-Y., Yen, C.-F., Chen, C.-S., \& Chen, C.-C. (2012). The association between Internet addiction and psychiatric disorder: A review of the literature. European Psychiatry, 27(1), 1-8. https://doi.org/10.1016/j.eurpsy.2010.04.011

Lee, J., Sung, M.-J., Song, S.-H., Lee, Y.-M., Lee, J.-J., Cho, S.-M., Park, M.-K., \& Shin, Y.-M. (2018). Psychological factors associated with smartphone addiction in south korean adolescents. The Journal of Early Adolescence, 38(3), 288-302. https://doi.org/10.1177/0272431616670751

Li, W., Diez, S. L., \& Zhao, Q. (2019). Exploring problematic internet use among non-latinx black and latinx youth using the problematic internet use questionnaire-short form (Piuq-sf). Psychiatry Research, 274, 322-329. https://doi.org/10.1016/j.psychres.2019.02.048

Liu, T. C., Desai, R. A., Krishnan-Sarin, S., Cavallo, D. A., \& Potenza, M. N. (2011). Problematic internet use and health in adolescents: Data from a high school survey in connecticut. The Journal of Clinical Psychiatry, 72(06), 836-845. https://doi.org/10.4088/JCP.10m06057

Maclean, J.S. (2017). FOMO, What's a Parent to do? :An Autoethno GrapHical Study of a Parent's Experiences of Their Adolecsent's Excessive Use of Social Media. Lancaster University, Kelvinside Academy. 1-52.

Mamun, M. A., \& Griffiths, M. D. (2019). The assessment of internet addiction in Bangladesh: Why are prevalence rates so different? Asian Journal of Psychiatry, 40, 46-47. https://doi.org/10.1016/j.ajp.2019.01.017

Marino, C., Gini, G., Angelini, F., Vieno, A., \& Spada, M. M. (2020). Social norms and e-motions in problematic social media use among adolescents. Addictive Behaviors Reports, 11, 100250. https://doi.org/10.1016/j.abrep.2020.100250

Mathew, P., \& Krishnan, R. (2020). Impact of problematic internet use on the self-esteem of adolescents in the selected school, Kerala, India. Archives of Psychiatric Nursing, 34(3), 122-128. https://doi.org/10.1016/j.apnu.2020.02.008

Montag, C., Lachmann, B., Herrlich, M., \& Zweig, K. (2019). Addictive features of social media/messenger platforms and freemium games against the background of psychological and economic theories. International Journal of Environmental Research and Public Health, 16(14), 2612. https://doi.org/10.3390/ijerph16142612

Moreno, M. A., Jelenchick, L. A., \& Christakis, D. A. (2013). Problematic internet use among older adolescents: A conceptual framework. Computers in Human Behavior,29(4), 1879-1887. https://doi.org/10.1016/j.chb.2013.01.053

Oberst, U., Wegmann, E., Stodt, B., Brand, M., \& Chamarro, A. (2017). Negative consequences from heavy social networking in adolescents: The mediating role of fear of missing out. Journal of Adolescence, 55, 51-60. https://doi.org/10.1016/j.adolescence.2016.12.008

Odacı, H., \& Çelik, Ç. B. (2013). Who are problematic internet users? An investigation of the correlations between problematic internet use and shyness, loneliness, narcissism, aggression and self-perception. Computers in Human Behavior, 29(6), 2382-2387. https://doi.org/10.1016/j.chb.2013.05.026

Okwaraji, F., Aguwa, E., Onyebueke, G., Arinze-Onyia, S., \& Shiweobi-Eze, C. (2015). Gender, age and class in school differences in internet addiction and psychological distress among adolescents in a nigerian urban 


\section{AJIT-e Bilişim Teknolojileri Online Dergisi \\ Academic Journal of Information Tecnology \\ 2021 Fall/Güz - Cilt/Vol: 12 - Sayı/Issue: 47 \\ doi) 10.5824/ajite.2021.04.001.x}

city. International Neuropsychiatric Disease Journal, 4(3), 123-131. https://doi.org/10.9734/INDJ/2015/18933

Pallanti, S., Bernardi, S., \& Quercioli, L. (2006). The shorter promis questionnaire and the internet addiction scale in the assessment of multiple addictions in a high-school population: Prevalence and related disability. CNS Spectrums, 11(12), 966-974. https://doi.org/10.1017/S1092852900015157

Panova, T., \& Carbonell, X. (2018). Is smartphone addiction really an addiction? Journal of Behavioral Addictions, 7(2), 252-259. https://doi.org/10.1556/2006.7.2018.49

Przybylski, A. K., Murayama, K., DeHaan, C. R., \& Gladwell, V. (2013). Motivational, emotional, and behavioral correlates of fear of missing out. Computers in Human Behavior, 29(4), 1841-1848. https://doi.org/10.1016/j.chb.2013.02.014

Riordan, B. C., Flett, J. A. M., Hunter, J. A., Scarf, D., \& Conner, T. S. (2018). Fear of missing out (Fomo): The relationship between FoMO, alcohol use, and alcohol-related consequences in college students. Journal of Psychiatry and Brain Functions, 2(1), 9. http://www.hoajonline.com/psychiatry/2055-3447/2/9

Roberts, J. A., \& David, M. E. (2020). The Social media party: fear of missing out (FoMO), social media intensity, connection, and well-being. International Journal of Human-Computer Interaction, 36(4), 386-392.

Rogers, A. P., \& Barber, L. K. (2019). Addressing FoMO and telepressure among university students: Could a technology intervention help with social media use and sleep disruption? Computers in Human Behavior, 93, 192-199. https://doi.org/10.1016/j.chb.2018.12.016

Rozgonjuk, D., Elhai, J. D., Ryan, T., \& Scott, G. G. (2019). Fear of missing out is associated with disrupted activities from receiving smartphone notifications and surface learning in college students. Computers \& Education, 140, 103590. https://doi.org/10.1016/j.compedu.2019.05.016

Rozgonjuk, D., Sindermann, C., Elhai, J. D., \& Montag, C. (2020). Fear of Missing Out (Fomo) and social media's impact on daily-life and productivity at work: Do WhatsApp, Facebook, Instagram, and Snapchat Use Disorders mediate that association? Addictive Behaviors, 110, 106487. https://doi.org/10.1016/j.addbeh.2020.106487

Ruggieri, S., Santoro, G., Pace, U., Passanisi, A., \& Schimmenti, A. (2020). Problematic Facebook use and anxiety concerning use of social media in mothers and their offspring: An actor-partner interdependence model. Addictive Behaviors Reports, 11, 100256. https://doi.org/10.1016/j.abrep.2020.100256

Sato, T. (2006). Internet addiction among students: Prevalence and psychological problems in Japan. Japan Medical Association Journal, 49(7/8), 279.

Simcharoen, S., Pinyopornpanish, M., Haoprom, P., Kuntawong, P., Wongpakaran, N., \& Wongpakaran, T. (2018). Prevalence, associated factors and impact of loneliness and interpersonal problems on internet addiction: A study in Chiang Mai medical students. Asian Journal of Psychiatry, 31, 2-7. https://doi.org/10.1016/j.ajp.2017.12.017

Spada, M. M. (2014). An overview of problematic Internet use. Addictive Behaviors, 39(1), 3-6. https://doi.org/10.1016/j.addbeh.2013.09.007

Thoumrungroje, A. (2014). The influence of social media intensity and EWOM on conspicuous consumption. Procedia-Social and Behavioral Sciences, 148, 7-15. 
Tifferet, S., \& Vilnai-Yavetz, I. (2014). Gender differences in Facebook self-presentation: An international randomized study. Computers in Human Behavior, 35, 388-399. https://doi.org/10.1016/j.chb.2014.03.016

TUIK. (2020). Youth in Statistics, 2019. Household internet usage rate of information and communication technology use report. Turkey Statistical Institute Newsletter, 33731.

Van Dijk, J. (2016). A $\breve{g}$ toplumu, Epsilon Yayincilik.

We Are Social Digital Report. (2020). Digital 2020 Global Digital Overview. Retrieved from https://wearesocial.com/digital-2020

Wolniewicz, C. A., Tiamiyu, M. F., Weeks, J. W., \& Elhai, J. D. (2018). Problematic smartphone use and relations with negative affect, fear of missing out, and fear of negative and positive evaluation. Psychiatry Research, 262, 618-623. https://doi.org/10.1016/j.psychres.2017.09.058

Wortham, J. (2011). Feel Like a Wallflower? Maybe It's Your Facebook Wall. Available at: https://www.nytimes.com/2011/04/10/business/10ping.html. (accessed 12 December 2019).

Yıldız, M. (2017). İletişim Sürecinde Sosyal Medya ve Sosyal Sermaye, The Journal of Social Science, 1 (2):7182. 